\title{
Sequencing-based phylogenetic-study of Babesia spp detected in tick tissues in Al-Diwaniyah province, Iraq
}

\author{
M.S. Hajeel and M.A.A. Al-Fatlawi* \\ Department of Microbiology, College of Veterinary Medicine, University of Al-Qadisiyah, Al-Diwaniyah, Iraq \\ * email: monyerr.abd@qu.edu.iq
}

(Received April 8, 2018; Accepted May 21, 2018)

\begin{abstract}
Our study purpose was to investigate the evolution of Babesia spp isolated from tissues of ticks that were found on 150 cows in Al-Diwaniyah province, Iraq. To fulfill the required purpose, sampling of 10 ticks was performed from each infested cow. These obtained ticks were morphologically recognized first, and then they were introduced to Lab investigation that was started with crushing the tick tissues to extract the genomic DNA of the Babesia spp. The DNA was then applied to polymerase chain reaction (PCR) method to recognize the amplification of the region that is related to the 18S rRNA gene. The resulted-amplified products were sequenced for the purpose of confirming and doing the phylogenetic analyses. Here, our study has demonstrated 2 different species according to the results of the sequencing and the phylogenetic analyses of the tested Babesisa species. These 2 species are SP1 and SP2. When the phylogenetic tree was built up, the results showed that SP1 and SP2 are closely related to Babesia bovis (HQ264126.1), an isolate from Texas, USA. Our study indicates interesting and valued data that could be used to study various aspects of the tick, Babesia species, and their control in Al-Diwaniyah City, Iraq.
\end{abstract}

Keywords: PCR, phylogeny, Babesia, tick Available online at http://www.vetmedmosul.com

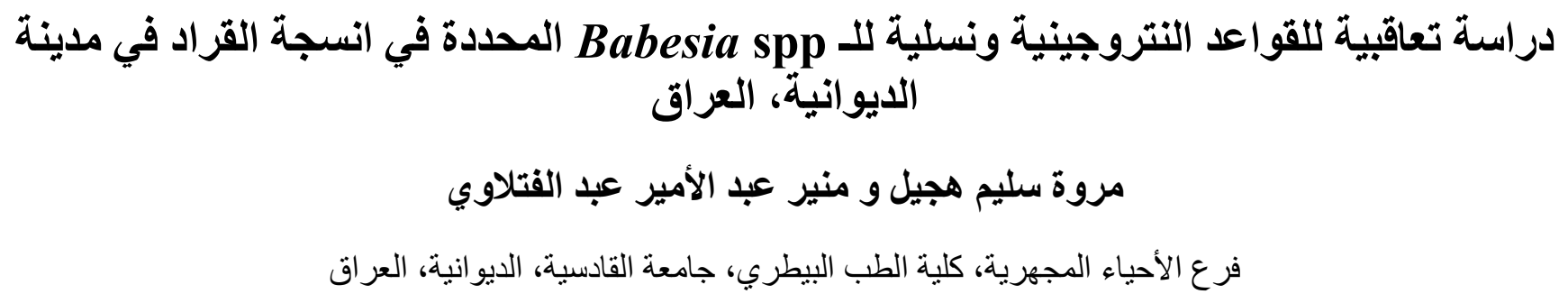

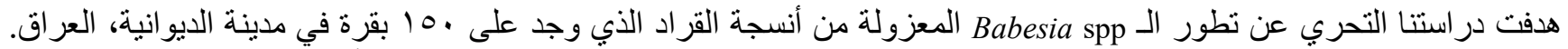

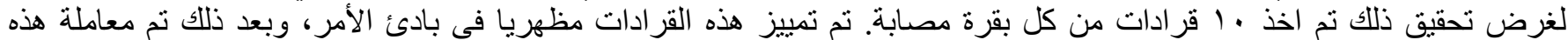

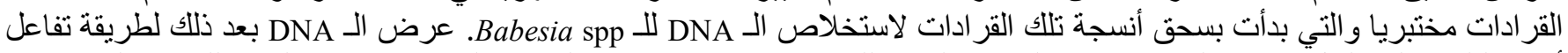

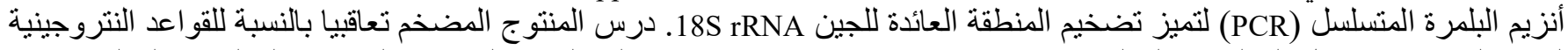

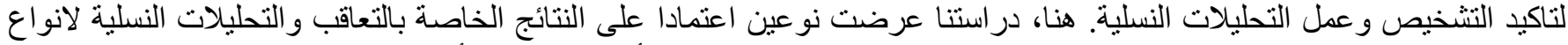

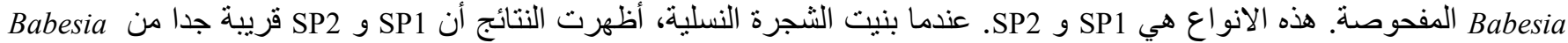
bovis (HQ264126.1) استخدامها لدر اسة جو انب مختلفة من القرادة، أنواع الـ لـ Babesia، و السيطرة عليهما في مدينة الديو انية، العراق. 


\section{Introduction}

The diseases that are caused by protozoa in animals induce major crises of economic and health losses around the world (1). Babesia-species members are globally recognized for their huge damages that they cause to the world industries of herds (2). Babesiosis is a tick-borne disease that generates a blood-based disease in different animals such as cows (3). Different genera and species of ticks such as Hyalomma and Rhipicephalus are well-known for their enhancement to transmit Babesia species to different animals (4). This microorganism has a lifestyle of asexual proliferation in animal hosts and a sexual-based life-style in ticks (5). A regular, but not too much trustworthy, diagnostic tool is the microscopic diagnosis of Babesia spp that has been used for decades till now to perform the diagnosis of this protozoan. However; relying on a high-error tool may lead to obtain false-negative results especially when having low numbers of parasites in blood samples of the tested animals that could be happened in subclinical and carrier cases. Microscopic diagnosis, sometimes, misses the capabilities to recognize between species level leaving the door open for indefinite diagnosis (6). For better diagnosis and identification of Babesia spp, molecular-based techniques such as PCR and sequencing of a specific-piece of sequence of a specific gene such as $18 \mathrm{~S}$ rRNA gene are needed to promote the processes of correct characterization, identification, and diagnosis of Babesia species that affect animals. These techniques are specially required when having low numbers of parasites in blood specimens of the studied animals (7). True insight information about the presence of certain species of Babesia in a given area of the world is generated via the use of molecular-based procedures such as sequencing and phylogenetic analyses (8). PCR and partial-18S-rRNA-gene sequencing were recruited to molecularly analyze Babesia spp isolated from ticks that affected cows in Al-Diwaniyah province, Iraq.

\section{Material and methods}

\section{Sampling and DNA extraction}

Our study purpose was to investigate the evolution of Babesia spp in tissues of ticks that were found on 150 out of 200 examined cows in Al-Diwaniyah province, Iraq. To fulfill the required purpose, sampling of 10 ticks was performed from each infested cow. These obtained ticks were morphologically recognized first according to (9) in the Iraqi Natural History Museum, and then they were introduced to lab investigation that was started with crushing 150 ticks to extract the genomic DNA of the Babesia spp. Extraction of the DNA was performed via the employment of gSYAN DNA mini extraction kit (Geneaid, USA), a tissue protocol. To prepare the tick tissues for the extraction process, an amount of $200 \mathrm{mg}$ of tick tissues was added in a $1.5-\mathrm{ml}$ tube, and an amount of $200 \mu 1$ of GST puffer was inserted into the tube. Then, crushing and homogenization steps were performed utilizing a micropestle. A NanoDrop was recruited to measure the DNA quality and quantity.

\section{Polymerase chain reaction and gel electrophoresis}

For the preparation of the mastermix, AccuPower PCR PreMix Kit was employed using DNA $5 \mu \mathrm{l}, 10$ pmol at 1.5 $\mu l$ of FP: GGGACGCCTCGTTACTTTGA and 10 pmol at $1.5 \mu \mathrm{l}$ of RP: TCCACCAACTAAGAACGGCC, $12 \mu \mathrm{H}_{2} \mathrm{O}$ for molecular biology. The kit protocol was used to finish the preparation process. NCBI website and primer 3 plus (Macrogen Company, Korea) were utilized to pick up the right primers. The PCR product at $551 \mathrm{bp}$ of the $18 \mathrm{~S}$ rRNA gene was targeted by the PCR amplification step. The conditions of the reactions were as follows: 1-cycle- $94{ }^{\circ} \mathrm{C}$ $5 \mathrm{~min}$ of initial denaturation, 35 cycles of $94^{\circ} \mathrm{C}-30 \mathrm{sec}$ denaturation, $58{ }^{\circ} \mathrm{C}-30 \mathrm{sec}$ annealing, and $72{ }^{\circ} \mathrm{C}-1 \mathrm{~min}$ extension, and 1-cycle-72 ${ }^{\circ} \mathrm{C}-5 \mathrm{~min}$ of final extension. Bands of the PCR products were transferred for separation purposes using electrophoresis via the use of $1.5 \%$ agarose gel at 100 volt and $80 \mathrm{amp}$ for duration of 1 hour. A UV imager was employed to visualize these product bands.

\section{8s rRNA gene partial sequencing}

Five-positive products at $551 \mathrm{bp}$ regarding the $18 \mathrm{~S}$ rRNA gene were sequenced. The sequences were NCBIbased processed to identify our obtained isolates using known world species. The phylogenetic tree was built up employing MEGA 6.0 software according to the basis of evolutionary distances via Maximum Composite Likelihood Method (10,11).

\section{Results}

The resulted-amplified products were sequenced for the purpose of confirming and doing the phylogenetic analyses. Here, our study has demonstrated 2 different species according to the results of the sequencing and the phylogenetic analyses of the tested Babesisa species. These 2 species are SP1 (MH109518.1) and SP2 (MH109519.1). When the phylogenetic tree was built up, the results showed that SP1 and SP2 are closely related to Babesia bovis (HQ264126.1), an isolate from Texas, USA, Figure 1. Our study indicates interesting and valued data that could be used to study various aspects of the tick, Babesia species, and their control in Al-Diwaniyah province, Iraq. 


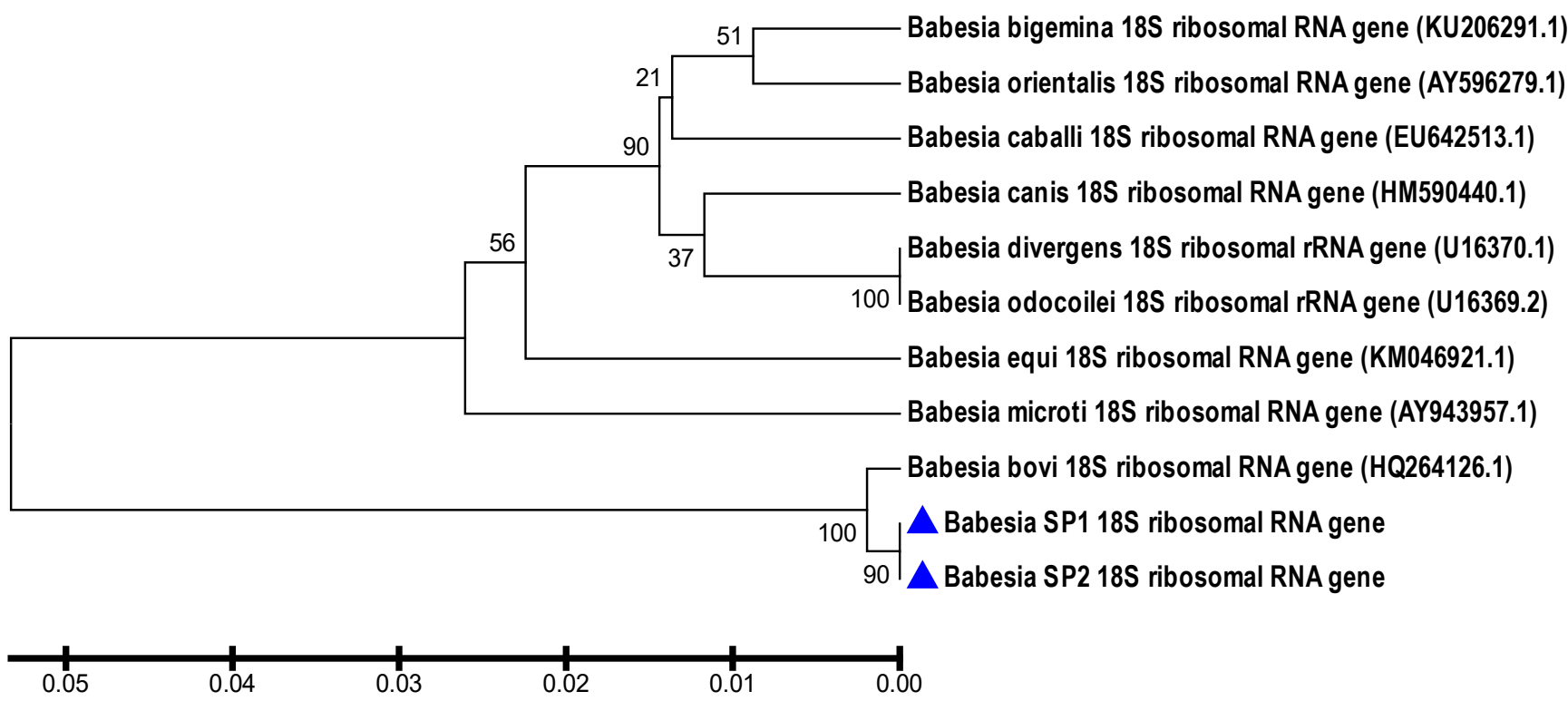

Figure 1: Phylogenetic tree of Babesia spp via the use of partial sequence of 18S rRNA gene, SP1 and SP2 are the current study species.

\section{Discussion}

The diseases that are caused by Babesia spp are diseases for global importance due to their effects on the economy and health system regarding food animals in the countries that these diseases are considered part of their listed tickborne diseases (12). The current study has utilized the 18SrRNA-gene-based sequencing to molecularly investigate the reality of species known to cause diseases in cows in Al-Diwaniyah City, Iraq. This sequencing has generated appealing findings regarding 2 isolated species of Babesia spp that were stand together in a very close neighboring to an isolate, Babesia bovis (HQ264126.1), from Texas, USA. The HQ264126.1 was identified using the partial sequencing of 18S rRNA gene of Babesia bovis from ticks infested white-tailed deer (13). This indicates that our species and the Texas one might have descended from one ancestor, and there are factors that play roles in spreading this ancestor around the world such as moving of animals and people and importation/exportation processes. This could also indicate that these isolates might have descended from a specific species related to different parts of the world other than USA or Iraq. The present-study findings agree with $(14,15)$ that identified Babesia spp via the use of molecular-based tools to diagnose and characterize the microorganism in the tested animals. Our study indicates interesting and valued data that could be used to study various aspects of the tick, Babesia species, and their control in Al-Diwaniyah City, Iraq. The big effect of ticks in transmitting Babesia species between cows is also unveiled by the information provided by the current study results. The accurate control of the diseases that are caused by Babesia spp needs to take in consideration important factors such as cost, validity, and the urgency in taking actions when an outbreak occurs. To fulfill these three factors, insight learning of the life of the protozoa in the city should be followed using various molecular methods.

\section{References}

1. Qiu Y, Kaneko C, Kajihara M, Ngonda S, Simulundu E, Muleya W, Thu MJ, Hang'ombe MB, Katakura K, Takada A, Sawa H, Simuunza M, Nakao R. Tick-borne haemoparasites and Anaplasmataceae in domestic dogs in Zambia. Ticks Tick Borne Dis. 2018;doi:10.1016/j.ttbdis.2018.03.025.

2. Greay TL, Zahedi A, Krige AS, Owens JM, Rees RL, Ryan UM, Oskam CK, Irwin PJ. Endemic, exotic and novel apicomplexan parasites detected during a national study of ticks from companion animals in Australia. Parasit Vectors. 2018;11(1):197. doi:10.1186/s13071-018-2775-y.

3. Da Rold G, Ravagnan S, Soppelsa F, Porcellato E, Soppelsa M, Obber F, Citterio CV, Carlin S, Danesi P, Montarsi F, Capelli G. Ticks are more suitable than red foxes for monitoring zoonotic tickborne pathogens in northeastern Italy. Parasit Vectors. 2018;11(1):137. doi:10.1186/s13071-018-2726-7.

4. Rajabi S, Esmaeilnejad B, Tavassoli M. A molecular study on Babesia spp. in cattle and ticks in West-Azerbaijan province, Iran. Vet Res forum Int Q J. 2017;8(4):299-306.

5. Hussein HE, Bastos RG, Schneider DA, et al. The Babesia bovis hap2 gene is not required for blood stage replication, but expressed upon in vitro sexual stage induction. PLoS Negl Trop Dis. 2017;11(10):e0005965.

6. Hailemariam Z, Krücken J, Baumann M, Ahmed JS, Clausen P-H, Nijhof AM. Molecular detection of tick-borne pathogens in cattle 
from Southwestern Ethiopia. PLoS One. 2017;12(11):e0188248. doi:10.1371/journal.pone. 0188248

7. Criado-Fornelio A. A review of nucleic-acid-based diagnostic tests for Babesia and Theileria, with emphasis on bovine piroplasms. Parassitologia. 2007;49(Suppl 1):39-44.

8. Criado-Fornelio A, Martinez-Marcos A, Buling-Saraña A, BarbaCarretero J. Molecular studies on Babesia, Theileria and Hepatozoon in southern Europe: Part II. Phylogenetic analysis and evolutionary history. Vet Parasitol. 2003;114(3):173-194. doi:10.1016/S03044017(03)00141-9.

9. Shubber H, Mohammed M, AlHassani N. Taxanomic, anatomic and molecular study of ixodid ticks parasitizing some mammals and birds in the middle and south of Iraq. PhD Thesis, University of AlQadisiyah. 2014

10. Saitou N, Nei M. The neighbor-joining method: a new method for reconstructing phylogenetic trees. Mol Biol Evol. 1987; 4:406-25. http://www.ncbi.nlm.nih.gov/pubmed/3447015 (accessed December $16,2017)$.

11. Tamura K, Stecher G, Peterson D, Filipski A, Kumar S. MEGA6: molecular evolutionary genetics analysis version 6.0., Mol Biol Evol. 2013;30:2725-9. doi:10.1093/molbev/mst197.
12. El-Ashker M, Hotzel H, Gwida M, El-Beskawy M, Silaghi C, Tomaso $\mathrm{H}$. Molecular biological identification of Babesia, Theileria, and Anaplasma species in cattle in Egypt using PCR assays, gene sequence analysis and a novel DNA microarray. Vet Parasitol. 2015;207:329-334. doi:10.1016/J.VETPAR.2014.12.025.

13. Holman PJ, Carroll JE, Pugh R, Davis DS. Molecular detection of Babesia bovis and Babesia bigemina in white-tailed deer (Odocoileus virginianus) from Tom Green County in central Texas. Vet Parasitol. 2011;177(3-4):298-304. doi:10.1016/j.vetpar.2010.11.052.

14. Elbaz E, Moustafa MAM, Lee K, Mohamed WMA, Nakao R, Shimozuru M, Sashika M, Younis EEA, El-khodery SA, Tsubota T. Molecular identification and characterization of piroplasm species in Hokkaido sika deer (Cervus nippon yesoensis), Japan. Tick Borne Dis. 2017;8:802-807. doi:10.1016/j.ttbdis.2017.06.007.

15. Jirapattharasate $C$, Adjou Moumouni PF, Cao S, Iguchi A, Liu M, Wang G, Zhou M, Vudriko P, Efstratiou A, Changbunjong T, Sungpradit S, Ratanakorn P, Moonarmart W, Sedwisai P, Weluwanarak T, Wongsawang W, Suzuki H, Xuan X. Molecular detection and genetic diversity of bovine Babesia spp., Theileria orientalis, and Anaplasma marginale in beef cattle in Thailand. Parasitol Res. 2017;116:751-762. doi:10.1007/s00436-016-5345-2. 